\title{
Strategic research on the construction of folk art history and creative industries in Guanzhong
}

\author{
Tu Jun \\ Associate Professor, School of Art, Xi'an University, Shaanxi, China, 710065
}

Keywords: folk art, history, creative industry

Abstract: This paper analyzes the internal relationship between the construction of folklore cultural history and creative industry by analyzing the current situation of the lack of original ecology faced by folklore art, and puts forward the idea of establishing the ecological system of folklore art and the structure of creative industry based on the clue of historiography. and at the same time to carry out the structural distribution around the clues of the history of folk art in Guanzhong, and to build the structure of creative industry in four steps, and the strategy and application of the creative industry is analyzed from three strategic development levels of microscopic, medium and macroscopic.

At present, with the urbanization process, folk culture is encountering an unprecedented crisis. The reasons are as follows: first, the transformation from farming civilization to industrial civilization has gradually lost the soil for the survival of traditional culture; second, folk culture in "fast-food economy" has been speeded up so that folk culture has lost the original ecological system balance; third, the collective attention for folk culture is not enough; fourth, folk art innovation is insufficient, and mechanical reproduction loses its original ecological emotions; fifth, facing the embarrassment of no successors. Folklore is the cultural image of a nation and the lifestyle created, enjoyed and inherited by the broad masses of the people. If we want to make it a cultural industry project to enhance the cultural image, we should not only implant the contemporary culture, but also maintain the distinct local cultural characteristics. Therefore, the study of Guanzhong folk art history as a starting point for innovation of cultural and creative industries is in line with the current content of cultural construction.

\section{Current Research Situation}

The study of folklore culture has now published more than 4500 books, 1900 periodicals and 965 dissertations, most of which are confined to areas or a certain category of art, such as folk art, festival customs, and taboos of belief, etc. Among them, Zhu Yaoting's "the study of Beijing Cultural History" (2008) put forward the suggestion that the study of folklore culture history is beneficial to the construction of citizen's image, which provides a certain reference for this study. The related papers on folklore culture are also concentrated on literature, historical and geographical direction, while there are less than 100 papers on industrial technology, agriculture, environmental science and economy. Relatively gratifying is that there are 74 patents, 69 research transformations, and 3 scientific and technological reports on folk culture related. Of the 147 
dissertations on the local folk culture in Guanzhong, about half are based on the practical application of engineering. Therefore, we can confidently demonstrate the importance of the construction of Guanzhong folk art history and the development of local cultural industrialization.

The construction of folklore culture history cannot be separated from the collation and control of folklore culture resources. Therefore, it is necessary to establish a system of folklore culture resources so as to build the overall framework of research. At present, there are about 2500 books, 1500 periodicals and 850 dissertations on folk culture resources and cultural industry. Such as, Chen Jianxian's "Folk Culture and Creative Industries" (2012), trying to systematically analyze of the close relationship between folk culture and creative industries combining macro and micro, theory and practice, from animation, film and television, games, festivals, tourism, advertising and other different angles; Liu Tongxia's "Research on the Regeneration Model of Folk Culture Resources" (2014) holds that folk culture itself has its inherent existence and evolution law, and has the characteristics of vulnerability and non-renewability. However, the rapid development of modern tourism overexploited and utilized folk culture, which caused irreversible negative impact. The most influential one is Dong Xiaoping's "A review of China's folk culture soft power development strategy" (Dong Xiaoping 2015). From the perspective of folklore, sociology and art, the paper analyzes the relationship between the construction of folklore culture and the construction of contemporary national social culture, and aims at the cultural relationship between the superiority of folklore culture and the consistency of the export of foreign culture under the network informationization. This theory has certain reference significance for this research.

On the basis of the analysis above, the existing literature and materials have reference and guidance significance for the research, and there are also deficiencies. Therefore, this paper will supplement and perfect in the following several aspects.

\section{Folk Culture History and Creative Industries.}

Folk culture reflects folk customs and a kind of cultural phenomenon of folk activities. Its surface structure is embodied in the materialization and behavior of folk customs. The deep structure is the psychological habits and concepts formed by the long-term accumulation of folk groups. As a study of folklore historiography, it pays more attention to the two existing forms of folklore culture, namely, the cultural state of folklore, the manifestation of systematic folklore matters, and the living state of folklore, the manifestation of its development and the part in progress. It also makes a historical inquiry into various folklore matters, seeking for change rules, in order to solve the problem of inheritance.

The term "creative industry" was first used in 1990 when Australia first published the concept of "creative nation" in Australia's cultural policy, which was later used by UK and other countries and regions. The UK defines it as an individual creative skill and talent through the production and use of intellectual property rights and industrial employment opportunities. Cultural economics regards creative industry as the combination of traditional non-profit arts and heritage with the for-profit cultural industry in "creative economy", which is regarded by many governments around the world as the main driving force for economic growth and employment.

Folk culture forms, as the carrier of cultural creativity, are managed by creative culture such as reproduction and commercialization of cultural industries. It promotes cultural production, such as technological means of production, large-scale production, market-oriented production purposes and industrialized production. Integration of industrial value chain and cultural brand shaping enhance the city's cultural strength. The implementation of three-dimensional interaction between production, ecology and life; the two-way integration of park and community, and the comprehensive coupling between town and city, change the passive and backward situation of our 
traditional folk culture with cultural power and creativity, in the same time assisting the development of creative leisure tourism, special crafts, industrial tourism, cultural tourism and leisure.

Folk culture historiography systematizes and regularizes the phenomena of folk culture, then combines and reconstructs the corresponding manifestations and creative industries, and constructs the development path and reconciliation strategy of current cultural and creative industries.

\subsection{Establishing the ecological system of folk custom based on the clue of historiography}

The ecological system of folklore is divided into three levels: ideology, cultural expression and artistic form to realize creative industry. As the diachronic development of local culture, historiography forms a sequence relationship, which can form different history is the expression of folklore level under space.

Diachronic is a linguistic concept proposed by Saussure. It focuses on the historical development, accumulation and change of language. In the study of literature and art, diachronic refers to the development of characters and events5. The folk culture characteristics of each place are accumulated from the continuous occurrence of folk events forming a living environment with life and experience. Repeated folk events in different historical periods form the accumulation of culture, forming a specific ideology, cultural expression and art form.

Ideology can be divided into material and immaterial folklore forms. Material folklore is a tangible kind of folk custom, and it can also be divided into material production folklore culture and material consumption folklore culture. In the process of production and consumption, the constant repetition of production and consumption gradually forms a fixed pattern and a pattern of culture, which is also a kind of repeated cultural form, thus making the group form the same mode of activity and culture.

This will be a study of profound significance. Ideology can also be divided into material and non-material folk-custom forms; cultural expression can be divided into culture and life state, which is the folk-custom cultural psychology and values showed in Festival folk-custom, production and life folk-custom, and the unique regional culture characteristics of folk culture in prominent areas. Art forms, through a systematic and comprehensive study of various cultural connotations, including dwellings, traditional handicraft skills, traditional performing arts, folk activities, ceremonies and festivals, and local customs, outline the long history of the development of folk arts, reveal the rich connotations and profound connotations contained in the customs of Guanzhong, create conditions for the integration of cultural construction and local economy.

\subsection{The Distribution of Creative Industry structure, Guanzhong area as an example}

It is divided into four steps around the structural distribution of the folk art history in Guanzhong. Firstly, the shaping and cultivation of citizens' cultural spirit, the interactive participation of performing arts and folk culture, and the guidance of community exchanges and cultural heritage in cities, villages and communities, including shadow play, lanterns, folk fires, puppets, Xi'an ancient music, kites and other comprehensive folk art forms; Secondly, the landscape creative construction of Guanzhong tourism industry and local context,In the overall image positioning of each city, we should grasp the folk culture characteristics of Guanzhong, and shape the city's spiritual and visual image; Thirdly, the construction of folk cultural communities and towns, including paper-cut, woodcut New Year pictures, peasant paintings, Shaanxi cloth art and other forms as the main content, such as paper-making skills, Yaozhou kiln and other practical arts and local cultural landscape combination application, in-depth investigation and tourism product development; Fourthly, the shaping of local folk culture and local place spirit in Guanzhong and the shaping of 
place spirit according to the spread of local folk history and culture.

To sum up, this topic from the strategic level of development and the application of countermeasures, from the macro point of view to suggest the combination of urban landscape, community and folklore culture, to strengthen the combination the scene, the region and folk customs; to construct the exhibition platform of festival culture and traditional folklore art from the view of middle view, that is, combining festival folklore with art exhibition; to develop the series of folk art derivatives from the micro perspective, bring about the strengthening and memory of local cultural symbols through the creative derivatives of folk art.

\section{Acknowledgements}

Xi'an Social Science Planning Project (Fund No.15WL23)

\section{References}

[1] Zhang Zichen, A dictionary of Chinese and foreign folklore [M]. Hangzhou: Zhejiang people's publishing house, 1991:175 - 176.

[2] He Xiaoyou, from "Made in China" to "Created in China" Higher Education in Industrial Design, Southeast University Press, 2016.12, P. 52

[3] Ruth Taos; Zhou Zhengbing's translation, Advanced introduction to cultural economics, Dongbei University of Finance and Economics press, 2016.05, Fifth

[4] Ruth Taos; Zhou Zhengbing's translation, Advanced introduction to cultural economics, Dongbei University of Finance and Economics press, 2016.05, Fifth

[5] Yin Jianzhong, Glossary of comparative literature terminology [M]. Beijing: Beijing Normal University Press, 2011:198

[6] Chen Hua Wen, A New course in Folk Culture, Zhejiang Industrial and Commercial University Press, 2014.02: 120

[7] Zhu Yaoting, editor-in-chief, A study of Beijing's Cultural History [M]. Beijing: Guangming Daily Press, 2008.05.

[8] Dong Xiaoping, A review of China's folk culture soft power development strategy [M]. Beijing:commercial Press, 20 15.08. 